\title{
Habitat Preference and Effects of Coastal Fragmentation in the Sand-Dwelling Spider Allocosa brasiliensis (Lycosidae, Allocosinae)
}

\author{
Carolina Jorge ${ }^{1,2 *}$, Álvaro Laborda², Marcelo Alves Días², Anita Aisenberg³, Miguel Simó \\ ${ }^{1}$ Instituto Superior de Estudios Forestales, CENUR Noreste sede Tacuarembó, Universidad de la República, \\ Tacuarembó, Uruguay \\ ${ }^{2}$ Sección Entomología, Facultad de Ciencias, Universidad de la República, Montevideo, Uruguay \\ ${ }^{3}$ Laboratorio de Etología, Ecología y Evolución, Instituto de Investigaciones Biológicas Clemente Estable, \\ Montevideo, Uruguay \\ Email: ${ }^{*}$ carolina.jorge@cut.edu.uy
}

Received 20 May 2015; accepted 6 July 2015; published 9 July 2015

Copyright (C) 2015 by authors and Scientific Research Publishing Inc.

This work is licensed under the Creative Commons Attribution International License (CC BY).

http://creativecommons.org/licenses/by/4.0/

(c) (;) Open Access

\begin{abstract}
Allocosa brasiliensis is a sand-dwelling wolf spider considered a good bioindicator to evaluate the quality of coastal dune ecosystems from Uruguay. Habitat fragmentation and human activities have impacted and reduced the Southern Uruguayan coast during the last decades. The aim of the present study was to evaluate the density, surface activity and habitat preference of $A$. brasiliensis in beaches with different human impact. For that purpose, we sampled during the night with head lamps and applied the capture-mark-recapture method. Females were more abundant than males and were the most recaptured sex. The most fragmented beaches showed lower number of burrows and individuals, especially in immatures stages. We found that the most suitable sandy habitat for $A$. brasiliensis should present a vegetation cover optimum of $25 \%-50 \%$ of the surface. This study could provide tools for the implementation of future management conservation plans of the Southern Uruguayan coastline.
\end{abstract}

\section{Keywords}

Allocosa brasiliensis, Wolf Spiders, Sandy Coast, Bioindicator, Ecology

\footnotetext{
"Corresponding author.

How to cite this paper: Jorge, C., Laborda, Á., Días, M.A., Aisenberg, A. and Simó, M. (2015) Habitat Preference and Effects of Coastal Fragmentation in the Sand-Dwelling Spider Allocosa brasiliensis (Lycosidae, Allocosinae). Open Journal of Animal Sciences, 5, 309-324. http://dx.doi.org/10.4236/ojas.2015.53035
} 


\section{Introduction}

Biodiversity loss as a consequence of human activity is one of the topics of environmental sciences that has focused more attention in the last two decades [1]. Several authors have cited examples of the reduction of biodiversity and abundance of arthropods (Butterflies [2], Crustaceans [3], arthropods assemblages of the sand-dunes [4] [5] among others) associated with the human impact. In Portugal, a study [3] proposed that the dune recovery mechanisms by building artificial shorelines in two sandy beaches studied were the responsible for the change in the macrofaunal assemblages and for the decline of the specialist species that was reflected in a biodiversity loss for this ecosystem. One of the main anthropic actions against conservation of biodiversity is habitat fragmentation in natural landscapes [6]. Habitat fragmentation negatively affects species communities in ecosystems, leading to the reduction of its natural areas, the isolation of their populations, increasing of edge effect, and consequently, causing a trend towards species extinction [7]. Nowadays, a quarter of the world's population lives in coastal areas [5] [8]. This phenomenon, along with the impacts of changes in land use, results in the alteration of coastal ecosystems in many parts of the planet, causing fragmentation and reduction of the natural environments [5] [9] [10]. Coastal areas generally are characterized by narrow shore parallel bands that comprise species assemblages specially adapted to live in changeable climatic conditions and environmental constraints such as strong winds, sand movements, high evaporation, high salinity, and limited nutrients [11] [12].

Sand dunes are distributed worldwide, mainly in tropical and temperate zones, with a great bio-geographical variation [12]. They are located along the littoral in sandy beaches [13]. Coastal dunes are essential links in the ecology of the beaches because they represent the border with the water, where this interface is characterized by the presence of physical, chemical and biological gradients [14]. One key for the conservation of the coastal dunes in fragmented landscapes is the knowledge of the biotic and abiotic components and the ecological relationships between them. The fauna in sandy beaches are dominated by arthropods, where spiders and other arachnids constitute an important part of invertebrate assemblages [7] [15]-[19]. Arthropods have been recognized as suitable ecological indicators of human stress and they have been used in monitoring plans for sandy coastal conservation [4] [20].

The original coastal landscape in Southern Uruguay used to be dominated by a wide sandy coastal strip with fixed and dynamic dunes associated to psammophile vegetation [16]. Since the twentieth century, urbanization reduced dramatically this wide coastal area to only a few meters in several zones along of the $714 \mathrm{~km}$ of coast at the South of the country [21]-[24]. This modification caused the reduction or loss of dunes, the replacement of native vegetation by exotic species, mainly Acacia longifolia (Andrews) Willd (Fabaceae), Pinus spp. (Pinaceae) and Eucalyptus spp. (Myrtaceae), and the fragmentation of the coast [25].

Studies carried out in the Uruguayan coast indicated that wolf spiders are abundant representatives of the fauna in sandy dunes [16]. Allocosa brasiliensis (Petrunkevitch, 1910) is a very common wolf spider in the Southern Uruguayan coastline. This nocturnal species constructs burrows in the sand [26]-[29], and shows sex-role reversal: males are bigger than females and females are the mobile sex that initiates courtship [30]. Copulation take place inside male burrows [30] [31] and males show reversed sexual cannibalism (they prey on rejected females) [18] [32]. A. brasiliensis shows morphological and behavioral features strongly associated to inhabiting the dune lines of natural sandy coasts and it has been catalogued as a good bio-indicator for coastal environments in Southern Uruguay [33]. The close relationship between the conservation of the dune line and the presence of Allocosa brasiliensis are strongly linked. Our aim was to know how landscape fragmentation impacts in the availability of a suitable habitat, population dynamics and density of A. brasiliensis. This knowledge could be critical for improving the efficiency of restoring plans of the dune lines in the Uruguayan Southern coast.

\section{Material and Methods}

\subsection{Study Area}

We chose two coastal sites of dissipative beaches in the coastal strip of Southern Uruguay. Site A was located in the Eastern region of Montevideo city, where beaches along $22 \mathrm{~km}$ of coast have been highly modified during several decades. The coastal ecosystem was drastically reduced to less than a hundred meters wide of sandy coast, conserving none or only one line of dunes. Furthermore, the coast has been fragmented in patches by sev- 
eral kinds of constructions where sand connections are interrupted [23]. Native psammophile vegetation was mainly reduced to the dune line, mostly represented by Panicum racemosum (P. Beauv.) (Poaciae), Senecio crassiflorus (Poir.) D. C. (Asteraceae) and Hydrocotyle bonariensis Lam. (Apiaceae). The Northern area of the beaches shows exotic vegetation such as Acacia longifolia and Pinus sp. [16] [33]. In this site, two neighboring beaches were selected for the study: the Mulata beach (M1) (34 $\left.{ }^{\circ} 53^{\prime} \mathrm{S}, 56^{\circ} 4^{\prime} \mathrm{W}\right)$ with $212 \mathrm{~m}$ long and Verde beach (M2) (34 $53^{\circ} \mathrm{S}, 56^{\circ} 4^{\prime} \mathrm{W}$ ) with $455 \mathrm{~m}$ long (Figure 1(A) and Figure 1(B)). These beaches are in process of being incorporated in an environmental beach management system and a restoring plan of the dune lines. Both beaches are separated by a yacht club and a spring along $200 \mathrm{mts}$. Site B is located in Canelones, $9.5 \mathrm{~km}$ to the East from site A. This is a $17 \mathrm{~km}$ long of coastline where beaches are wider and less fragmented, mostly with two fixed dune lines with native psammophile vegetation and connected with patches of floodplain plant communities. The edge of the coast with urbanization presents forestation with exotic species similarly to what was indicated above for site A. We selected two beaches with similar length than those chosen for Montevideo: Lagomar (C1)

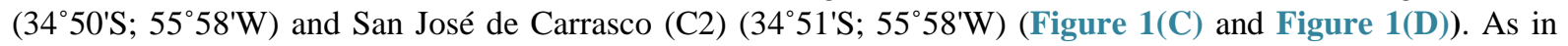
site A, both areas are separated $200 \mathrm{~m}$ from each other, but in site B there is no interruption of the sandy coast. The temperature during the data collection was between $11.6^{\circ} \mathrm{C}$ to $25^{\circ} \mathrm{C}$ in site $\mathrm{A}$ and in site $\mathrm{B}$ the temperature was between $16.9^{\circ} \mathrm{C}$ to $26^{\circ} \mathrm{C}$.

\subsection{Sampling Design}

Field work was performed biweekly from October 2009 to January 2010. This period was chosen because it coincided with the reproductive season where the species presents the highest surface activity [28] [30] [31]. Due to its crepuscular habits, we performed night samplings with visual detection of the exemplars by using head lamps. We sampled four plots covering the first line of dunes, the nearest to the coast line, on each beach: (M1 and C1: $50 \times 50 \mathrm{~m}$, in small beaches; M2 and C2: $100 \times 50 \mathrm{~m}$, large beaches). We counted all walking individuals and burrows of $A$. brasiliensis on each plot. We sexed the individuals and later released them. To estimate individual mobility we used the capture-mark-recapture method, this method has been used to study the surface activity, home range and population dynamics in wolf spiders and other ground hunters species [34]-[37]. We only considered adults and juveniles in penultimate or antepenultimate stage. The marking was done with permanent markers, on the dorsal region of the abdomen. Each mark showed a characteristic color and shape combination that allowed us to identify each specimen when it was recaptured. This method was previously tested in the laboratory where the ink did not cause damage to spiders or changes in their behavior. Data from recaptures were taken 24 hours after spiders being marked and during the study period. Due to bad weather con-
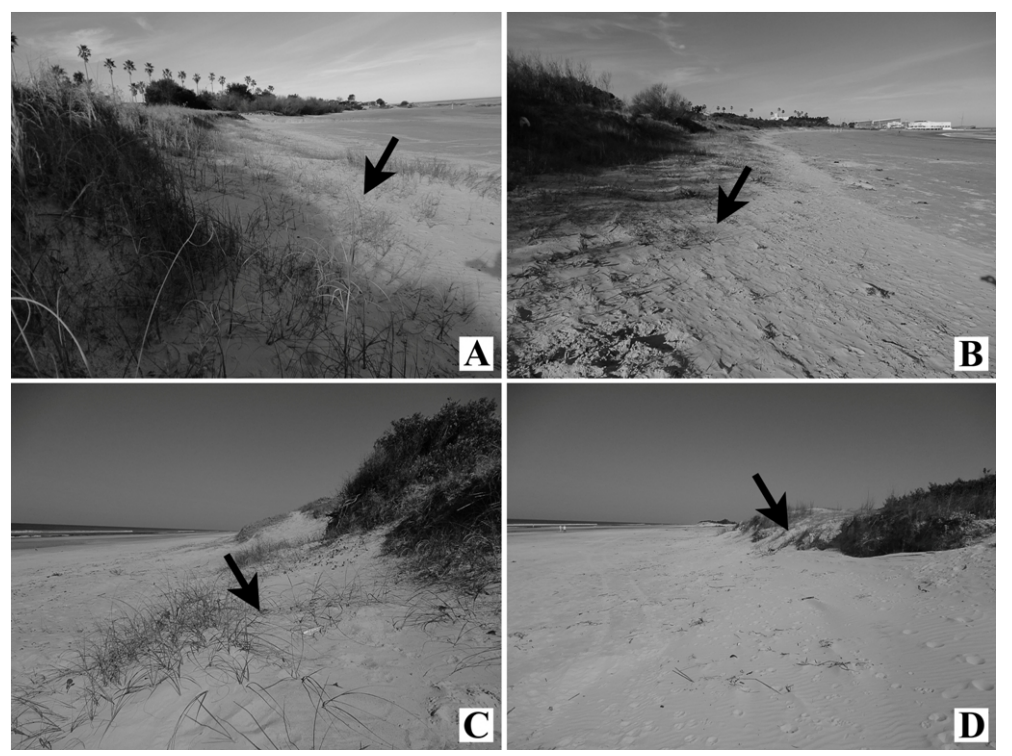

Figure 1. Study areas. A, B, Site A: A = Mulata (M1), B = Verde (M2). C, D, Site B: C = Lagomar (C1), D = San José de Carrasco (C2). 
ditions, only in three cases we did not perform the samplings 24 hours after capture, and they were performed between 2 - 5 days after. The spider records were geo-referenced to determine the distance between the capture and recapture sites. Vegetation cover was measured following the Braun-Blanquet method [38]. Ten quadrats $\left(0.25 \mathrm{~m}^{2}\right)$ were georreferenciated where surface activity was reported to be higher, along a transect on each site (A and B). We calculated Braun-Blanquet density score and frequency for each psammophile plant species at each quadrat. Density was calculated as the average value of the Braun-Blanquet score in all the quadrats surveyed by site. The Braun-Blanquet cover scale utilized: $r$ : 1 or few individuals; 1 : low abundance, with cover $<5 \%$; 2: cover 5\% - 20\%; 3: cover $25 \%$ - 50\%; 4: cover 50\% - 75\%; *: quadrat without vegetation cover.

\subsection{Data Analysis}

At a regional scale, data were compared between the two sites (A and B) and at local scale between beaches of each site (see [39]). We used spider density to allow comparisons between plots of different sizes. The normality and homogeneity of variances were checked with Shapiro Wilk and Levene tests, respectively [40]. Data distribution did not fit the requirements for parametric tests so we finally used the non parametric test Mann-Whitney U-Test [41] to test the null hypothesis of no difference in density of marked, recaptured and non-marked specimens of A. brasiliensis between the sites. We used a hierarchical cluster analysis to explore how the plots were grouped in base to the similarity of the spider density, using the Bray Curtis as similarity index for the construction of the dendrogram (constrained, Unweighted Pair Group Method Average (UPGMA) algorithm and Bootstrap $N=2000$ ) [40] [42]. We also applied the Non Metric Dimensional Scaling analysis (NMDS) using the Bray Curtis as similarity [43]. This technique is commonly used in ecological studies, specially to evaluate if the environmental disturbance affects the species composition, association of arthropods with plant species and other relationships between species and other biotic or abiotic variables [40] [44] [45]. The goodness of this method is the stress, which relates the distance between objects in a small space considering its similarity [44] [46]. It is considered that stress values greater than 0.25 are too poor to explain the presence or not of possible patterns that connect the species with the sites [46].

The capture points and the displacement distance of marked individuals were calculated on satellite images using Google Earth (http://earth.google.com/). For the study of the suitable area of the species, each plot was divided into four zones based on presence or absence of dunes and by the cover vegetation type: A: dune with psammophile vegetation; B: zone with exotic species of shrubs and trees; C: open sandy areas outside the dune and roads for traffic people through the beach; D: intertidal zone. Based on satellite images, the four zones were delimited in polygons and analyzed with Qgis 2.2. Valmiera [47]. Density of marked spiders in each zones were considered for estimating habitat preference using the Kruskal-Wallis non-parametric analysis of variance. If we found significant differences, the Mann-Whitney test with the Bonferroni correction was applied. To test whether there was a correlation between temperature and the number of specimens observed, we performed a simple linear regression analysis of the density of $A$. brasiliensis in function with the temperature. This relation was analyzed at local and a regional scale. A Chi ${ }^{2}$ was calculated for comparing paired frequency data on the base of an expected distribution. Data analyses were performed using Past Paleontological Statistics Software $2.16[48]$.

\section{Results}

\subsection{Abundance}

In site A, we registered 247 individuals and marked 147 exemplars (54.4\% in M2), and in site B we observed 663 individuals and marked 246 individuals (57\% in C2) (Table 1). At each beach, the highest abundance and density of this species were found on the dunes (M1 = 89\%, M2 = 91\%, C1 =93\%, C2 = 77\%) (Figure 2).

At a regional scale, spider abundance was higher in site $\mathrm{B}\left(\mathrm{Chi}^{2}: p=0.0001\right.$; Mann-Whitney test: $\mathrm{U}=26$; $\mathrm{p}=$ 0.0086) (Table 1). Differences were also found when comparing the abundance of spiders between beaches of the site A and B with the same size: $\mathrm{M} 1$ versus $\mathrm{C} 1(\mathrm{U}=32 ; p=0.02)$ and $\mathrm{M} 2$ versus $\mathrm{C} 2(\mathrm{U}=18.5 ; \mathrm{p}=0.002)$. The sex ratio was biased to females both at regional (site $A: U=135, p=0.0013$; site $B: U=115.5, p=0.00032$ ) and local scales (M1: $\mathrm{U}=35, \mathrm{p}=0.029 ; \mathrm{M} 2: \mathrm{U}=34, \mathrm{p}=0.027$; $\mathrm{C} 1: \mathrm{U}=26, \mathrm{p}=0.0079$ and $\mathrm{C} 2: \mathrm{U}=31.5, \mathrm{p}=$ $0.018)$. At a regional scale female $(U=242 ; \mathrm{p}=0.343)$ and male $(\mathrm{U}=281, \mathrm{p}=0.889)$ abundances were not significant. The number of burrows was 3 times higher in site B than in site A (Mann-Whitney test, $\mathrm{U}=115, p=$ 0.0003) (Table 1). 


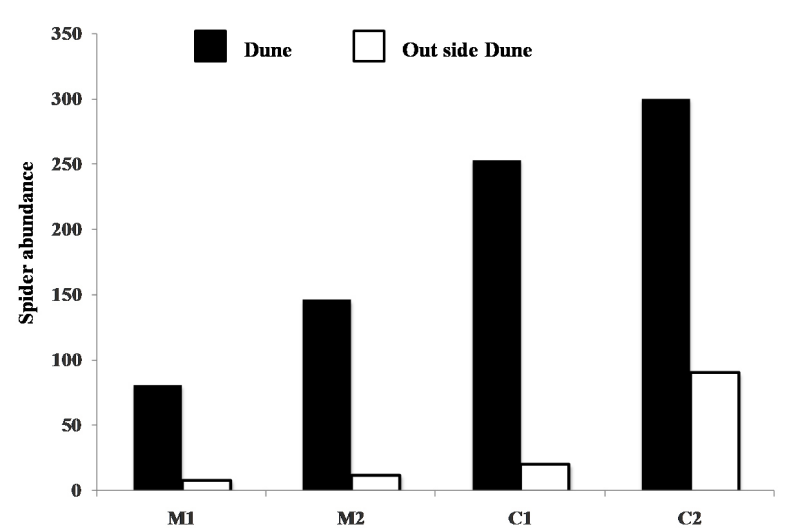

(a)

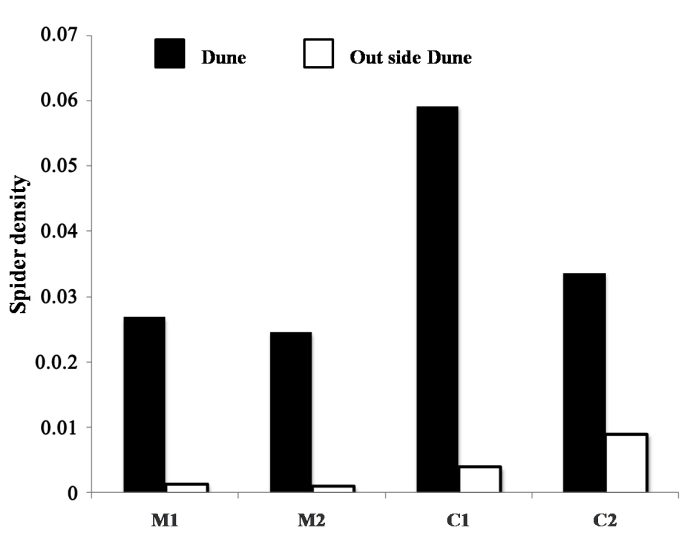

(b)

Figure 2. (a) Abundance of exemplars of sand-dwelling wolf spider (A. brasiliensis) observed in dunes or outside dunes in the studied beaches; (b) Density of A. brasiliensis observed in dunes or outside dunes in the studied beaches.

Table 1. Abundance of specimens of sand-dwelling wolf spider (A. brasiliensis) observed in the study sites. MM: marked males, MF: marked females, MI: marked immatures. TM: totally marked, R: recaptures, I: not marked immatures, B: burrows.

\begin{tabular}{ccccc}
\hline & & Beaches & & \\
Categories & Site A-M1 & Site A-M2 & Site B-C1 & Site B-C2 \\
\cline { 2 - 5 } MM & 12 & 20 & 16 & 13 \\
MF & 31 & 36 & 48 & 46 \\
MI & 24 & 24 & 42 & 140 \\
TM & 67 & 80 & 3 & 2 \\
R & 11 & 1 & 167 & 250 \\
I & 22 & 78 & 88 & 101 \\
B & 26 & 37 & & 25 \\
\hline
\end{tabular}

\subsection{Density}

We found differences in density between sites A and B ( $U$ = 26; $p=0.00856)$, but not at a local scale (Table 2). The cluster analysis (cophenetic correlation $=0.8822$ ) (Figure 3 ) and the NMDS analysis showed differences between sites $\mathrm{A}$ and $\mathrm{B}$ (stress index $=0$ ), further indicating that the shortest beach in the most fragmented site (M1) appears clearly separated from the rest of the beaches (Figure 4). Furthermore, NMDS indicates that the beaches of the Site B are more similar to each other than beaches of the Site A (Figure 4).

\subsection{Habitat Preference and Temperature}

The records and density of specimens were higher at the dune line (Figure 2 and Figure 5; Table 3). The Kruskal-Wallis test showed significant differences in the density of marked exemplars between the four zones of each beach (Table 4).

At a local scale, the NMDS analysis showed that zones with different vegetation cover appear as two isolated fragments in site A (M1-M2: stress index $=0.24)$ conversely to beaches of the site B where zones showed high connection between them (C1-C2: stress index $=0.15$ ) (Figure 6). Of all the plots surveyed, the spider density was higher in the line of dunes (Table 3), showing significant differences with areas occupied by exotic species of shrubs or trees (Table 4). Regarding the existence of a relationship between temperature and spider's density, at a local scale, the beaches did not present a linear relationship. The same was observed when we analyzed the data at a regional scale (Site A: $\mathrm{p}=0.587$; Site B: $\mathrm{p}=0.238$ ) (Figure 7(a) and Figure 7(b). But when we com- 


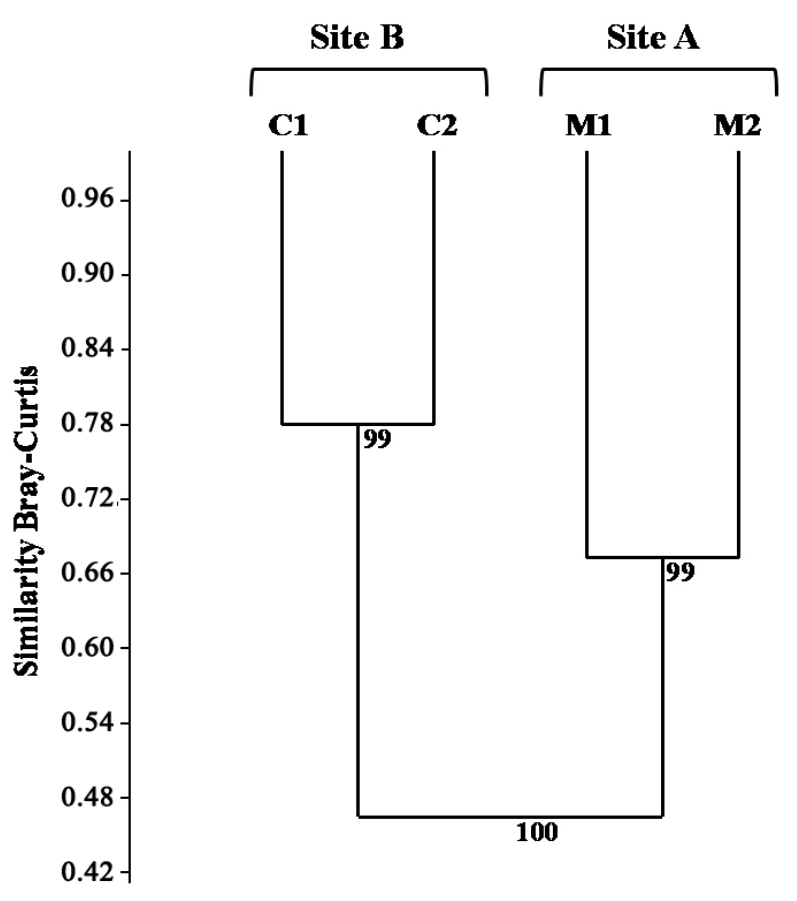

Figure 3. Dendrogram of the relationship of the density A. brasiliensis in the studied beaches using the Bray Curtis similarity index (I. coph coor: 0.8808). M1: Mulata, M2: Verde, C1: Lagomar and C2: San José de Carrasco.

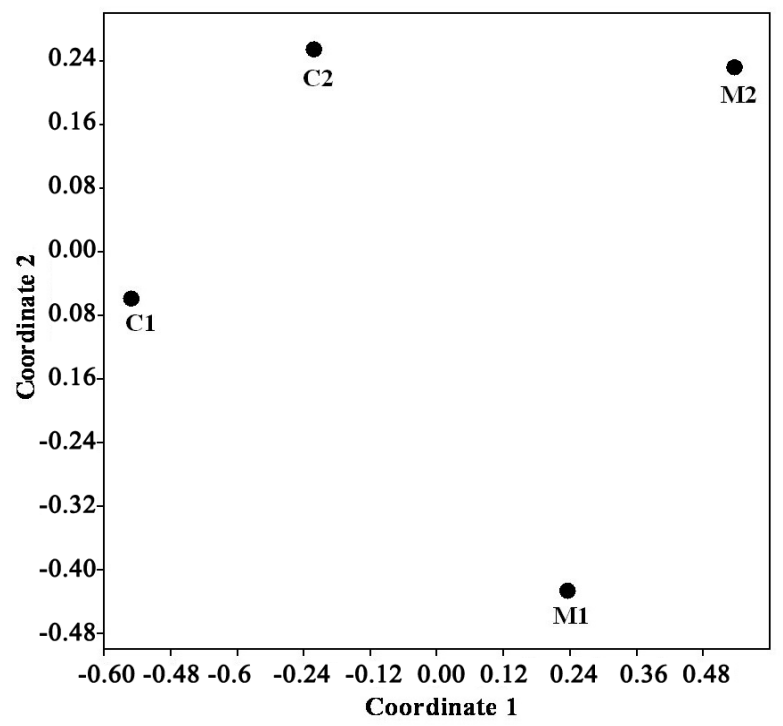

Figure 4. Non-metric multidimensional scaling (NMDS) of the density of $A$. brasiliensis in the four studied beaches using the Bray-Curtis similarity index. M1: Mulata, M2: Verde, C1: Lagomar and C2: San José de Carrasco.

pared all the data set in the study beaches as if it was a single population, we found a mild linear trend between the spider density and temperature $(r=0.3803 ; p=0.008)$ (Figure $7(\mathrm{c})$ ).

We observed three psammophile plant species in the quadrats. $P$. racemosum presented the higher values of abundance, rating an average of 2.1 (Site B) to 2.5 (Site A) in the Braun-Blanquet cover scale, which represents 

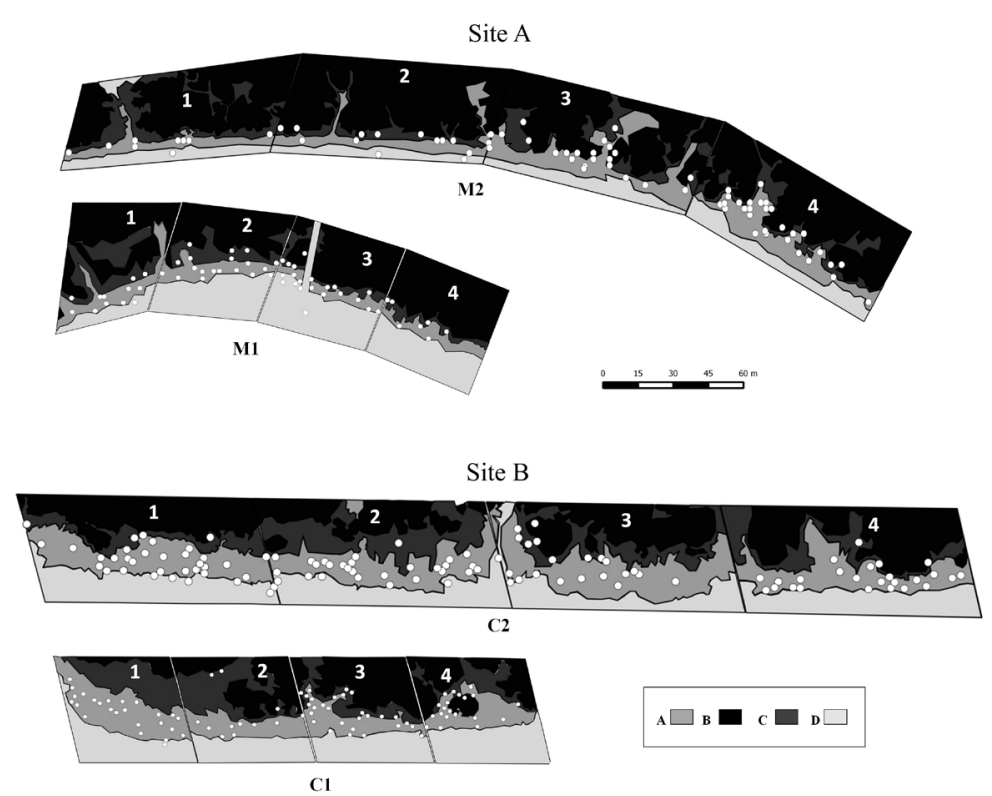

Figure 5. Spatial distribution of marked specimens of A. brasiliensis in different vegetation types in beaches of sites A and B. A: dune with psammophile vegetation, B: zone with exotic species of shrubs and trees, C: open sandy areas outside the dune, D: intertidal zone. M1: Mulata, M2: Verde, C1: Lagomar and C2: San José de Carrasco.

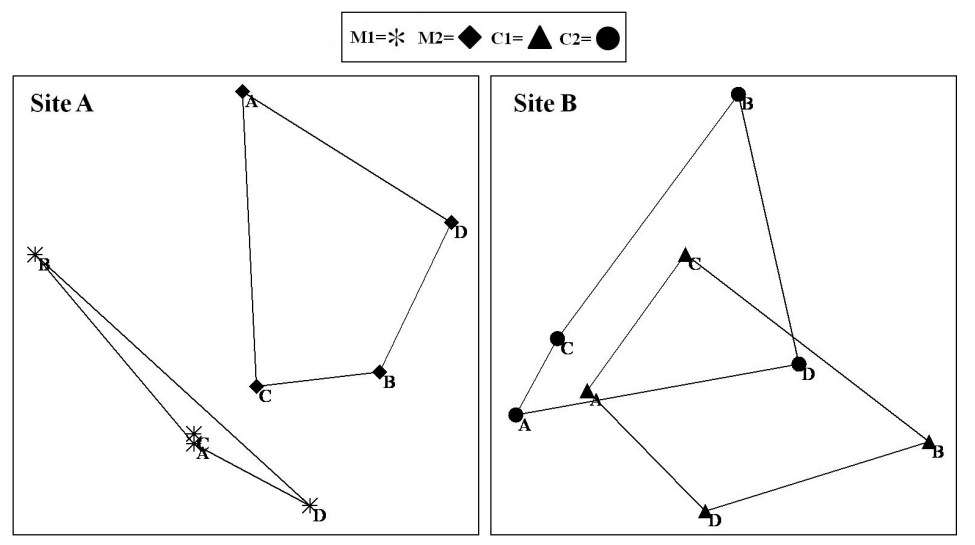

Figure 6. NMDS analysis of habitat preference of A. brasiliensis in sites A and $\mathrm{B}$, using the Bray-Curtis similarity index as a measure. M1: Mulata, M2: Verde, C1: Lagomar and C2: San José de Carrasco, A: dune with psammophile vegetation, B: zone with exotic species of shrubs and trees, C: open sandy areas outside the dune, D: intertidal zone.

$25 \%-50 \%$ of the quadrats surface analyzed (Table 5). Furthermore, this species was the most frequent with values of $90 \%$ (Site A) to $80 \%$ (Site B) of presence in the quadrats analyzed. The others two species registered were H. bonariensis and S. crassiflorus but with lower frequency and coverage (Table 5).

\subsection{Recaptures and Distances Covered}

We recaptured 17 exemplars of $A$. brasiliensis along the study (4.3\%). Females were the most recaptured sex with 53\% of the cases. Highest values of recapture (16.4\%) were observed in M1 (site A) (Table 6). We found significant differences in the total number of marked and recaptured individuals between sites $\mathrm{A}$ and $\mathrm{B}\left(\mathrm{Chi}^{2}=\right.$ 


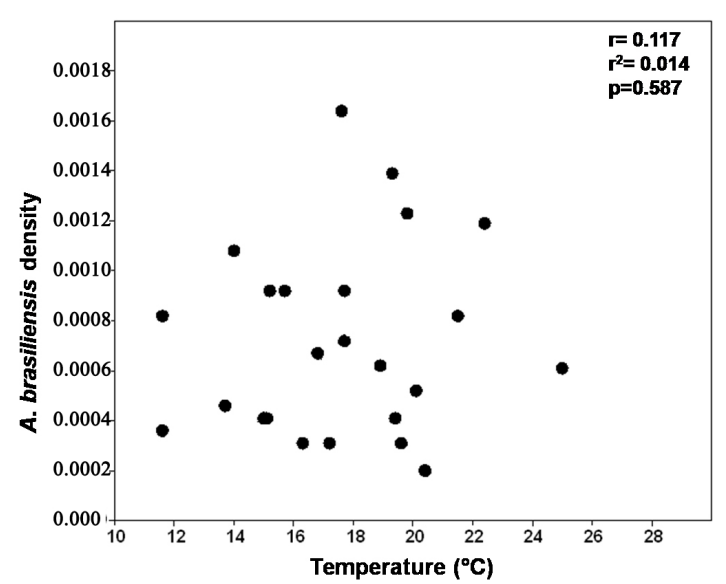

(a)

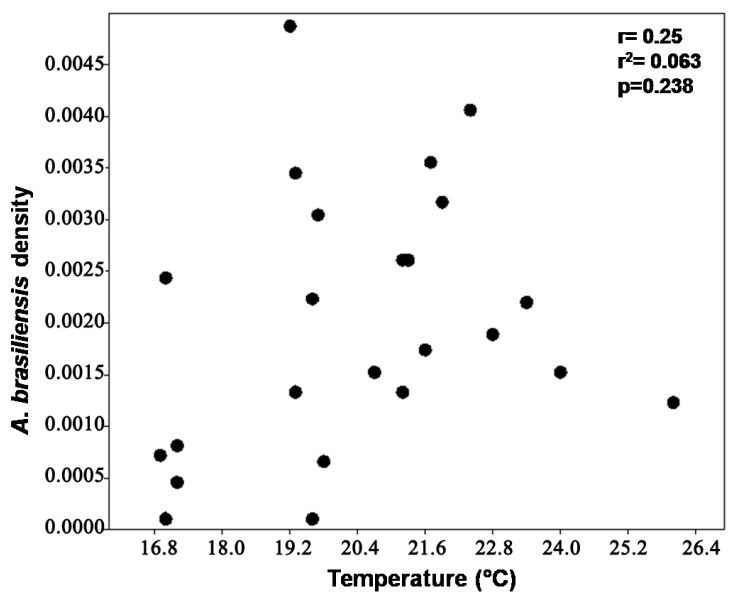

(b)

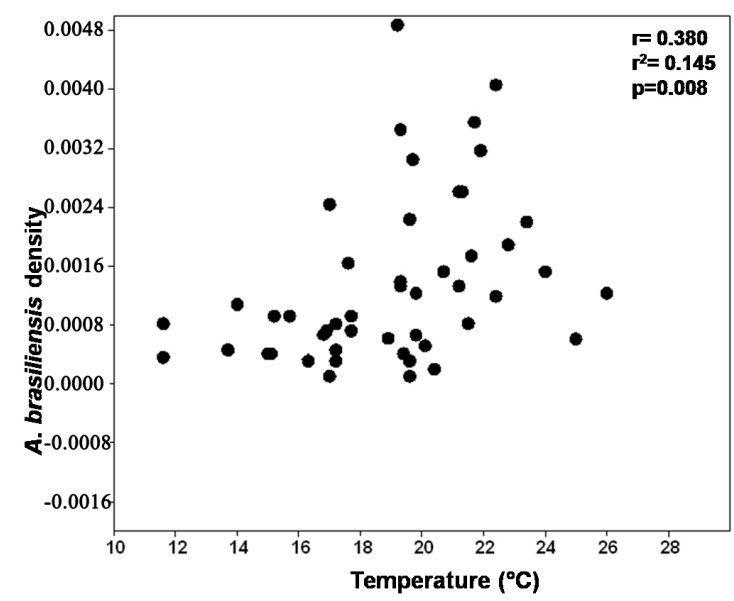

(c)

Figure 7. Comparison of the density of the marked and observed exemplars with the temperature in A. brasiliensis: (a) Site A; (b) Site B; (c) Both sites.

Table 2. Comparisons of density of $A$. brasiliensis between beaches. $U$ = Mann-Whitney (U test) with the Monte Carlo correction. $\mathrm{p}=$ statistical significance. In bold letters, statistically significant values $(\mathrm{p} \leq 0.05)$.

\begin{tabular}{ccccc}
\hline \multirow{2}{*}{ Beaches } & \multicolumn{2}{c}{ Marked specimens } & \multicolumn{2}{c}{ Immature + marked } \\
\cline { 2 - 5 } C1 vs. C2 & $\mathrm{U}$ & $\mathrm{p}$ & $\mathrm{U}$ & $\mathrm{p}$ \\
M1 vs. M2 & 53 & 0.2851 & 52 & 0.2598 \\
M1 vs. C1 & 40 & 0.06812 & 66 & 0.7501 \\
M1 vs. C2 & 47 & 0.1564 & 33 & $\mathbf{0 . 0 2 6 0}$ \\
M2 vs. C2 & 41.5 & 0.8396 & 25.5 & $\mathbf{0 . 0 0 7 8}$ \\
C1 vs. M2 & 54 & 0.3114 & 19 & $\mathbf{0 . 0 0 2 4 1}$ \\
A vs. B & 32 & $\mathbf{0 . 0 2 2 3 1}$ & 27 & $\mathbf{0 . 0 1 0 1 4}$ \\
\hline
\end{tabular}

7.41; $\mathrm{p}=0.006)$. Most of the specimens were recaptured within 24 hours after marking. M1, showed higher values of recaptures $(\mathrm{N}=11)$.

A positive correlation between time and distance of recapture was observed at a regional scale in site $\mathrm{B}$ ( $\mathrm{n}=$ 
Table 3. Area, abundance and density of A. brasiliensis for each zone and beach N: abundance. A: dune with psammophile vegetation, B: zone with exotic species of shrubs and trees, C: open sandy areas outside the dune, D: intertidal zone. $a=a b-$ undance; $d$ = density. Area in square meters.

\begin{tabular}{|c|c|c|c|c|c|c|c|c|c|c|c|c|}
\hline \multirow{2}{*}{ Vegetation zones } & \multicolumn{2}{|c|}{$\mathrm{C} 1$} & \multicolumn{3}{|c|}{ C2 } & \multicolumn{3}{|c|}{ M1 } & \multicolumn{4}{|c|}{ M2 } \\
\hline & Area & a & d & Area & a & d & Area & $\mathrm{a}$ & d & Area & $\mathrm{a}$ & d \\
\hline A & 2406 & 78 & 0.0324 & 5560 & 102 & 0,0183 & 1188 & 35 & 0.0295 & 3275 & 49 & 0.015 \\
\hline B & 2421 & 3 & 0.0012 & 5462 & 2 & 0.0004 & 4143 & 2 & 0.0005 & 10604 & 9 & 0.0008 \\
\hline C & 1870 & 21 & 0.0112 & 3379 & 16 & 0.0047 & 1834 & 23 & 0.0125 & 2684 & 21 & 0.0078 \\
\hline D & 2786 & 4 & 0.0014 & 4603 & 20 & 0.0043 & 2300 & 7 & 0.003 & 2317 & 1 & 0.004 \\
\hline
\end{tabular}

Table 4. Comparisons of density of $A$. brasiliensis per plot in the studied beaches. Kruskal-Wallis test. $\mathrm{p}=$ statistical significance. In bold letters, statistically significant values $(\mathrm{p} \leq 0.05)$.

\begin{tabular}{|c|c|c|c|c|c|c|c|c|c|c|c|c|c|c|c|c|}
\hline \multirow{2}{*}{ Plots } & \multicolumn{4}{|c|}{ C1 } & \multicolumn{4}{|c|}{$\mathrm{C} 2$} & \multicolumn{4}{|c|}{ M1 } & \multicolumn{4}{|c|}{ M2 } \\
\hline & 1 & 2 & 3 & 4 & 1 & 2 & 3 & 4 & 1 & 2 & 3 & 4 & 1 & 2 & 3 & 4 \\
\hline$A$ vs $B$ & 0.001 & 0.229 & 0.001 & 0.007 & 0.001 & 0.0001 & 0.012 & 0.001 & 0.002 & 0.006 & 0.098 & 0.069 & 0.014 & 0.039 & 0.066 & 0.002 \\
\hline A vs $C$ & 0.001 & 0.79 & 0.358 & 0.314 & 0.0001 & 3 E-05 & 0.317 & 0.014 & 0.033 & 0.753 & 0.974 & 0.859 & 0.178 & 0.437 & 0.258 & 0.315 \\
\hline A vs D & 0.003 & 0.070 & 0.002 & 0.003 & 6 E-03 & 0.004 & 0.099 & 0.47 & 0.071 & 0.018 & 0.179 & 0.069 & 0.014 & 0.006 & 0.002 & 0.001 \\
\hline B vs C & - & 0.229 & 0.006 & 0.104 & 0.003 & 0.317 & 0.230 & 0.148 & 0.149 & 0.015 & 0.097 & 0.148 & 0.069 & 0.223 & 0.755 & 0.002 \\
\hline B vs D & 0.317 & 0.317 & 0.229 & 0.317 & 0.015 & 0.952 & 0.229 & 0.006 & 0.148 & 0.317 & 0.684 & - & - & 0.149 & 0.014 & 0.952 \\
\hline C vs D & 0.317 & 0.070 & 0.025 & 0.033 & 0.148 & 0.317 & 0.732 & 0.129 & 0.859 & 0.044 & 0.179 & 0.148 & 0.069 & 0.032 & 0.070 & 0.002 \\
\hline
\end{tabular}

$\left.11 ; \mathrm{r}=0.924 ; \mathrm{r}^{2}=0.854 ; \mathrm{b}=2.4703 ; \mathrm{p}=0.025\right)$ and when we analyzed the total data of recaptures $(\mathrm{n}=17 ; \mathrm{r}=$ $\left.0.857 ; \mathrm{r}^{2}=0.734 ; \mathrm{b}=1.427 ; \mathrm{p}=0.0000112\right)$ (Figure 8). In site A values were almost near significant $(\mathrm{N}=12 ; \mathrm{r}$ $\left.=0.570 ; \mathrm{r}^{2}=0.325 ; \mathrm{b}=2.2219 ; \mathrm{p}=0.053\right)$. The distance of displacement of the spiders ranged between 0 to 115.4 meters. One male from M1 (Site A) and a one female from C1 (site B) presented the highest values of distance and recapture time period (54.1 meters in 26 days; 115.4 in 53 days respectively (Table 6).

\section{Discussion}

This study revealed that $A$. brasiliensis presents higher values of abundance and density in less reduced and fragmented beaches with more availability of open dunes as site B (Table 1 and Table 2). These beaches offer more suitable areas for constructing burrows, better cryptic condition against predators and reduce the competition with other wolf spiders, as Schizocosa malitiosa (Tullgren, 1905), which it is associated with sandy habitats impacted by human influence [16].

The chance of an organism to inhabit a certain fragmented habitat depends on its ability to move among exotic and original patches of vegetation [49]. In all the beaches, females were more abundant than males and they were the sex with higher recaptures (Table 1, Table 6). This is in agreement with the sex-role reversal reported for this species [30] [31], and consequent higher mobility in this sex. Also, females of A. brasiliensis need to forage intensively before mating because after that they will remain buried in male burrows, ovipositing there and exiting for spiderling dispersal, approximately one month later [18] [29] [31]. Intense foraging activity will also be reflected by high surface activity during the summer of the Southern hemisphere.

The reduction of suitable habitat in combination with fragmentation may lead to a decrease in dispersal rates, promoting the isolation of populations [50]. Our results showed that the highest displacement and recapture time was recorded in less fragmented beaches suggesting more dispersal and probably higher longevity. As was expected, recaptures were more frequent in the beach with less suitable habitat for the species (M1), where patches of dunes with psammophile vegetation were scarce (Figure 5). The higher number of individuals and burrows were observed in the dunes, which indicates that the main surface activity of the species takes place on these 
Table 5. Abundance plant and score of the Braun-Blanquet cover scale. r: 1 or few individuals; 1 : low abundance, with cover $<5 \%$; 2: cover 5\% - 20\%; 3: cover $25 \%$ - 50\%; 4: cover 50\% - 75\%; *: quadrat without vegetation cover.

\begin{tabular}{|c|c|c|c|c|}
\hline Site & Quadrat & Species & Abundance & Score \\
\hline A & 1 & P. racemosum & 7 & 2 \\
\hline A & 2 & P. racemosum & 14 & 3 \\
\hline A & 3 & P. racemosum & 22 & 3 \\
\hline A & 4 & S. crassiflorus & 6 & + \\
\hline A & 4 & P. racemosum & 18 & 4 \\
\hline A & 5 & P. racemosum & 17 & 2 \\
\hline A & 6 & P. racemosum & 9 & 2 \\
\hline A & 6 & Brassica sp. & 2 & $\mathrm{r}$ \\
\hline A & 7 & S. crassiflorus & 6 & 2 \\
\hline A & 8 & P. racemosum & 32 & 2 \\
\hline A & 9 & P. racemosum & 23 & 3 \\
\hline A & 9 & H. bonariensis & 1 & r \\
\hline A & 10 & P. racemosum & 22 & 2 \\
\hline B & 1 & P. racemosum & 11 & 2 \\
\hline B & 1 & Oenothera mollisima L. & 1 & $\mathrm{r}$ \\
\hline $\mathrm{B}$ & 2 & P. racemosum & 4 & 2 \\
\hline B & 3 & P. racemosum & 25 & 3 \\
\hline B & 3 & H. bonariensis & 4 & 1 \\
\hline B & 3 & S. crassiflorus & 1 & $\mathrm{r}$ \\
\hline B & 4 & P. racemosum & 25 & 4 \\
\hline $\mathrm{B}$ & 5 & P. racemosum & 25 & 4 \\
\hline B & 6 & P. racemosum & 8 & 3 \\
\hline B & 7 & S. crassiflorus & 1 & $\mathrm{r}$ \\
\hline B & 8 & S. crassiflorus & 11 & 1 \\
\hline B & 8 & P. racemosum & 14 & 2 \\
\hline B & 9 & - & - & - \\
\hline B & 10 & P. racemosum & 3 & 1 \\
\hline B & 10 & H. bonariensis & 3 & 1 \\
\hline B & 10 & Oenothera mollisima L. & 1 & $\mathrm{r}$ \\
\hline
\end{tabular}

areas of the coastal coastline (Figure 5). [51] indicated an association between the structure and diversity of vegetation with the distribution of dune spiders in sandy coasts of North-West England. [16] reported the presence of A. brasiliensis in the dunes lines of the southern Uruguayan coast. Our study showed that the species is mainly present in dunes covered with psammophile vegetation in relation with sandy areas outside the dune (Figure 6). This habitat preference could be due to the fact that the sand in fixed dunes is less compacted, what can facilitate the construction of the burrows (Figure 1). Also, open habitats can help localization of male burrows by the females. Surfaces where the species was rare or absent presented humid and more compacted sand 
Table 6. Recapture data of A. brasiliensis. F: female, M: male, I: immature. Displacement: distance between mark and recapture points.

\begin{tabular}{|c|c|c|c|}
\hline Beach & Sex & Recapture period (days) & Displacement (m) \\
\hline M1 & $\mathrm{F}$ & 1 & 9.5 \\
\hline M1 & $\mathrm{F}$ & 1 & 13.3 \\
\hline M1 & I & 1 & 8.4 \\
\hline M1 & I & 5 & 15.9 \\
\hline M1 & $\mathrm{F}$ & 9 & 0.5 \\
\hline M1 & $\mathrm{F}$ & 9 & 3.8 \\
\hline M1 & $\mathrm{F}$ & 1 & 23.2 \\
\hline M1 & $\mathrm{F}$ & 1 & 10.2 \\
\hline M1 & I & 1 & 3.83 \\
\hline M1 & I & 2 & 14.5 \\
\hline M1 & M & 26 & 54.1 \\
\hline M2 & M & 15 & 2.58 \\
\hline $\mathrm{C} 1$ & $\mathrm{~F}$ & 13 & 4.9 \\
\hline $\mathrm{C} 1$ & $\mathrm{~F}$ & 53 & 115.4 \\
\hline $\mathrm{C} 1$ & $\mathrm{~F}$ & 2 & 2.4 \\
\hline $\mathrm{C} 2$ & $\mathrm{~F}$ & 1 & 31.3 \\
\hline $\mathrm{C} 2$ & I & 1 & 7.9 \\
\hline
\end{tabular}

as it was observed in the inter-tidial zone or surfaces occupied by exotic vegetation which show a thick mulch of leaf litter covering the sand. Moreover, sandy areas without psammophile vegetation reported few specimens, probably due they represent trails where people walk to the beach, and for this reason they are not suitable sites for burrow construction (Figure 5). Habitat structure is closely linked to microclimatic influences which determine spider distribution [52]. In recent restored dunes, the spider colonizes only when psammophile vegetation is fixed in the sand (M. Simó (personal observation, 2012)). Our results indicate that $A$. brasiliensis is very sensitive to changes in the vegetation cover of the sand. Dunes with psammophile vegetation were the best predictors to find a burrow or surface activity for this species. In contrast, leaf litter in patches with exotic vegetation was a negative indicator for A. brasiliensis occurrence. This result agrees with studies on other sandy wolf spider as Geolycosa xera, that show that this spider species and leaf litter substrata are mutually exclusive [53].

The present study indicates that $A$. brasiliensis showed higher rates of mobility and higher number of burrows in beaches with more availability of the dune lines with psammophile vegetation, condition that constitute the best suitable habitat for the species establishment (Table 1, Table 6, Figure 2 and Figure 5). Construction of burrows implies energetic costs associated with silk production to maintain stable the walls of the burrow and costs of digging activities per se, and a high risk of predation due to the performance of conspicuous behaviors at the open field while digging [28]. In this scenario, the substrate seems important for a more efficient digging. Along with this, field observations suggest a potential high rate of relocation of the burrows, something expected if we consider the changeable conditions of coastal environments. [29] indicated that adult burrows of $A$. brasiliensis were more frequent at the base of sand-dunes where humidity values were higher. Furthermore, they observed that temperature buffering increased with depth, providing thermal stability and good conditions for eggs development. The presence of psammophile vegetation in open sandy areas represent a critical component to preserve the suitable habitat conditions for the species and avoid the negative effects of high levels of evotranspiration and temperature changes.

Our results are agree with [33] in the sense that $P$. racemosum is the more frequent plant species in the $A$. 


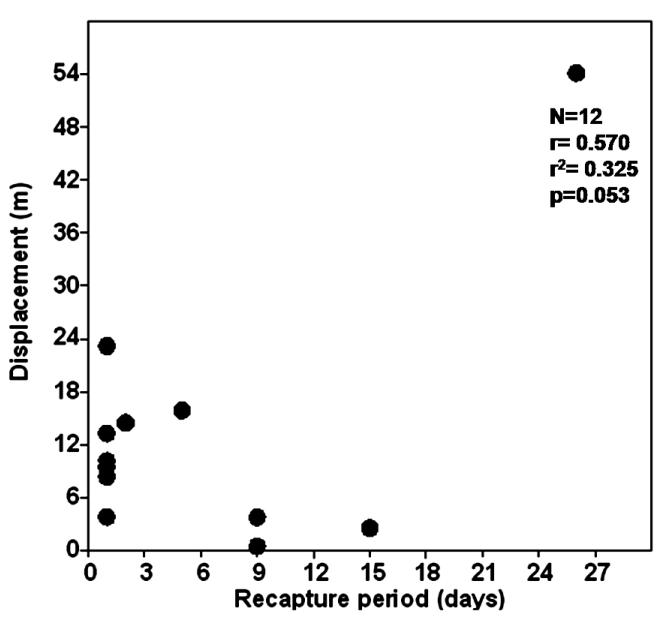

(a)

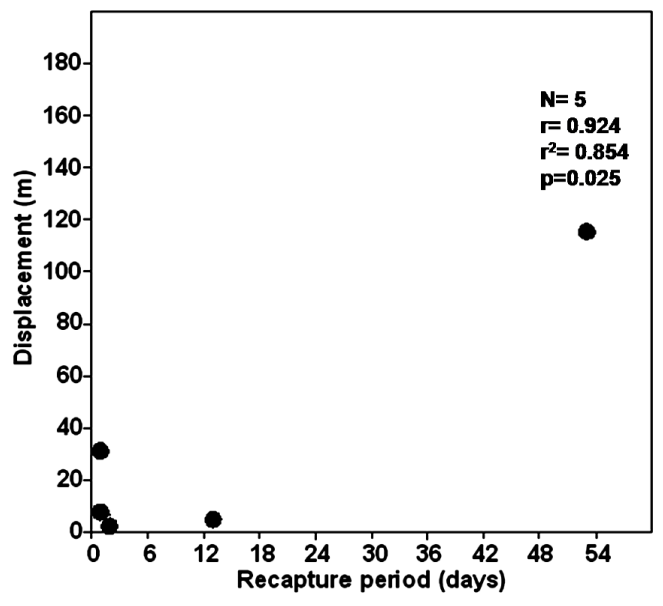

(b)

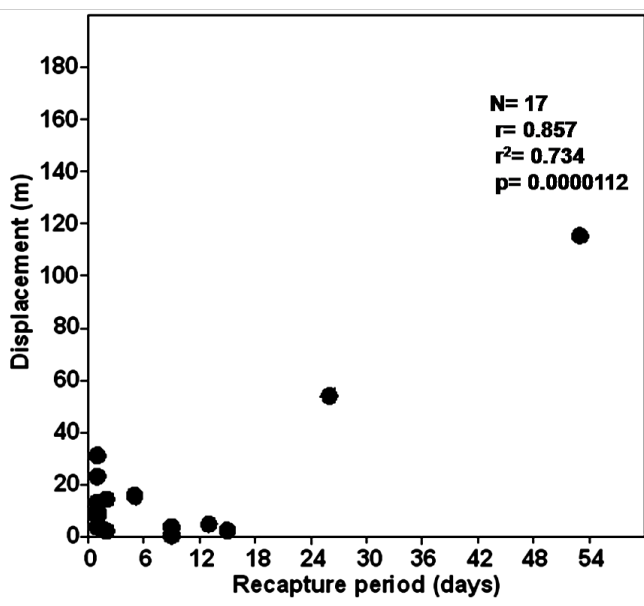

(c)

Figure 8. Linear relationship of the time of recapture and distance covered of the recaptured individuals of $A$. brasiliensis. (a) site (a) (b): site (b) (c): both sites. N: number of exemplars recaptured.

brasiliensis habitat. As these authors indicated, other two native species were also reported in the present study as $S$. crassifolius and $H$. bonariensis (Table 5). All these are considered dune-forming species based in the structure of rhizomes [33] [54]. The vegetation cover here studied, indicated that the most suitable sandy habitat for A. brasiliensis should present a vegetation cover of $25 \%$ - $50 \%$ of the surface (Table 5). We argue that this percentage is optimum because it has the compaction of the sand needed for burrow building. Furthermore, $P$. racemosum probably could play a critical role in the dispersal way of the species by ballooning. [15] indicated that the reduction of suitable habitat and fragmentation increased selection pressures that affect behavioural traits conducting reduction of the dispersal rates in the wolf spider Pardosa monticola Clerck, 1757 from dune habitats of Netherlands. Along with this, and although the dispersal mechanisms of $A$. brasiliensis are not well known, the species could be influenced by the fragmentation habitat reducing ballooning but increasing the cursorial dispersion.

This species presents the reproductive period and its higher surface activity in warmer months [16] [18]. As was expected, we found that for most beaches A. brasiliensis density increased with temperature (Figure 7). During summer concurrence of people to the beaches is high and this fact seems to be negative in M1, probably because the suitable area was the smallest of the beaches we studied. Also, unlike other beaches of this study, M1 registered the highest number of recaptures what associated with the lowest number of spiders and burrows, suggesting the occurrence of a small and probably threatened local population. To get a more realistic view of which factors most affect the population abundance and density of A. brasiliensis we should have a more time of 
counting and tracking individuals in the field.

Studies with alive spiders in their natural habitat are difficult because we cannot control all variables (temperature, antropic modifications, precipitation, preys offer, among others) that may influence in the results. Another aspect to consider was the duration of the study, we only could follow a period of their highest surface activity, because the project that financed this study should be conducted in a year. These can have been some of our study's limitations. Therefore it would be like a photograph of what was happened with these populations of $A$. brasiliensis at this time, with this environmental conditions and this should not affected the outcome of the study. In order to avoid these limitations, future researches will be aimed at evaluating the effect of dune recovery practices such as, wood runners for the access to the beach, influence of the dune recovery procedure applied, among others and increase the time of the population monitoring.

The spatial analysis revealed a high level of fragmentation in site A, where patches of different ground cover zones are clearly isolated between neighboring beaches (Figure 6). Habitat degradation, often associated with anthropogenic impact, could lead to reduced diversity and density with declining fragment size and increasing fragment age [55]. Moreover, it was reported that ground active spiders, could increase significantly in density and morpho-species richness with increasing fragment age [56]. As was indicated by [57], retention of small fragments at small intervals across a broad geographical scale appears to be an important element of any plan for biodiversity conservation. [4] remarked the importance of the knowledge of the bio-ecology of the sandy dune macro-invertebrates of the sandy dune, previous to restoration plans in order to order to evaluate and minimize the impact during this process.

\section{Conclusion}

This study provides data to be applied in environmental management plans of restoration and conservation of the Uruguayan coastal line considering A. brasiliensis as bio-indicator. Finally, we would like to highlight the importance of restoring connections between patches of fixed dunes with native vegetation to allow mobility and gene flow among populations of species inhabiting Uruguayan coastal areas. Further studies could be focused in evaluating other factors such as beaches with different stages of conservation and the effects of tourism on the natural history of this species.

\section{Acknowledgements}

To Agencia Nacional de Investigación e Innovación (ANII) which awarded a grant for performing this study to C. Jorge. To Manuel Castro, David Ortiz, Cintya Perdomo, Demian Gómez, Valeria Rodríguez, Leandro Giulliani and Fiorella Benvenutto for their help in the field work. To Eduardo Alonso-Paz and Carlos Brussa for the identification of the plant species, to José Carlos Guerrero for his assistance with the geographic information systems, to Walter Norbis for his help with the statistical analysis and his comments on this manuscript.

\section{References}

[1] Díaz, S., Fargione, J., Chapin, F.S. and Tilman, D. (2006) Biodiversity Loss Threatens Human Well-Being. PLoS Biology, 4, 1300-1305. http://dx.doi.org/10.1371/journal.pbio.0040277

[2] Ravenscroft, N.O.M. (1994) Environmental Influences on Mate Location in Male Chequered Skipper Butterflies, Carterocephalus palaemon (Lepidoptera:Hesperiidae). Animal Behaviour, 47, 1179-1187. http://dx.doi.org/10.1006/anbe.1994.1156

[3] Bessa, F., Cunha, D., Correia Gonçalves, S. and Marques, J.C. (2013). Sandy Beach Macrofaunal Assemblages as Indicators of Anthropogenic Impacts on Coastal Dunes. Ecological Indicators, 30, 196-204. http://dx.doi.org/10.1016/j.ecolind.2013.02.022

[4] Bessa, F., Goncalves, S.C., Franco, J.N., Andréd, J.N., Cunhae, P.P. and Marques, J.C. (2014) Temporal Changes in Macrofauna as Response Indicator to Potential Human Pressures on Sandy Beaches. Ecological Indicators, 41, 49-57. http://dx.doi.org/10.1016/j.ecolind.2014.01.023

[5] Nourisson, D.H., Bessa, F., Scapinia, F. and Marques, J. (2014) Macrofaunal Community Abundance and Diversity and Talitrid Orientation as Potential Indicators of Ecological Long-Term Effects of a Sand-Dune Recovery Intervention. Ecological Indicators, 36, 356-366. http://dx.doi.org/10.1016/j.ecolind.2013.08.005

[6] Santos, T. and Tellería, J.L. (2006) Pérdida y fragmentación del hábitat: Efecto sobre la conservación de las especies. Ecosistemas, 15, 1-7. 
[7] Vandergast, A.G. and Gillespie, R.G. (2004) Effects of Natural Forest Fragmentation on a Hawaiian Spider Community. Enviromental Entomology, 33, 1296-1305. http://dx.doi.org/10.1603/0046-225X-33.5.1296

[8] Rivadeneira, M.M., Santero, C.M. and Marquet, P.A. (2010) Reconstructing the History of Human Impacts on Coastal Biodiversity in Chile: Constraints and Opportunities. Aquatic Conservation, 20, 74-82.

[9] Defeo, O., McLachlan, A., Schoeman, D.S., Schlacher, T.A., Dugan, J., Jones, A., Lastra, M. and Scapini, F. (2009) Threats to Sandy Beach Ecosystems: A Review. Estuarine Coastal Shelf Science, 81, 1-12. http://dx.doi.org/10.1016/j.ecss.2008.09.022

[10] Teixido, A.L., Quintanilla, L.G., Carreño, F. and Gutiérrez, D. (2010) Impacts of Changes in Land Use and Fragmentation Patterns on Atlantic Coastal Forests in Northern Spain. Journal of Environmental Management, 91, 879-886. http://dx.doi.org/10.1016/j.jenvman.2009.11.004

[11] Carter, R.W.G. (2002) Coastal Environments. An Introduction to the Physical, Ecological and Cultural Systems of Coastlines. California Academic Press, San Jose.

[12] Greipsson, S. (2002) Coastal Dunes. In: Perrow, M.R. and Davy, A.J., Eds., Handbook of Ecological Restoration. Volume 2. Restoration in Practice, Cambridge University Press, Cambridge, 214-237.

[13] Maun, M.A. (2009) The Biology of Coastal Sand Dunes. Oxford University Press, New York.

[14] Mc Lachlan, A. (1991) Ecology of Coastal Dune Fauna. Journal of Arid Environments, 21, 229-243.

[15] Bonte, D., Baert, L. and Maelfait, J.P. (2002) Spider Assemblage Structure and Stability in a Heterogeneous Coastal Dune System (Belgium). Journal of Arachnology, 30, 331-343. http://dx.doi.org/10.1636/0161-8202(2002)030[0331:SASASI]2.0.CO;2

[16] Costa, F.G., Simó M. and Aisenberg, A. (2006) Composición y ecología de la fauna epígea de Marindia (Canelones, Uruguay) con especial énfasis en las arañas: Un estudio de dos años con trampas de intercepción. In: Menafra, R., Rodríguez-Gallego, L., Scarabino, F. and Conde, D., Eds., Bases para la conservación y el manejo de la costa uruguaya, Vida Silvestre Uruguay, Montevideo, 427-436.

[17] Cardoso, P., Silva, I., de Oliveira, N.G. and Serrano, A.R.M. (2004) Indicator Taxa of Spider (Araneae) Diversity and Their Efficiency in Conservation. Biological Conservation, 120, 517-524. http://dx.doi.org/10.1016/j.biocon.2004.03.024

[18] Aisenberg, A., González, M., Laborda, A., Postiglioni, R. and Simó M. (2009) Foraging and Surface Activities of Allocosa alticeps and Allocosa brasiliensis (Lycosidae), Two Sex-Role Reversed Spiders from Coastal Sand Dunes. The Journal of Arachnology, 37, 135-138. http://dx.doi.org/10.1636/T08-52.1

[19] Buchholz, S. (2009) Community Structure of Spiders in Coastal Habitats of a Mediterranean Delta Region (Nestos Delta, NE Greece). Animal Biodiversity Conservation, 32, 101-115.

[20] Lucrezi, S., Schlacher, T.A. and Robinson, W. (2009) Human Disturbance as a Cause of Bias in Ecological Indicators for Sandy Beaches: Experimental Evidence for the Effects of Human Trampling on Ghost Crabs (Ocypode spp.). Ecological Indicators, 9, 913-921. http://dx.doi.org/10.1016/j.ecolind.2008.10.013

[21] Lercari, D. and Defeo, O. (2003) Variation of a Sandy Beach Macrobenthic Community along a Human-Induced Environmental Gradient. Estuarine, Coastal and Shelf Science, 58, 17-24.

http://dx.doi.org/10.1016/S0272-7714(03)00043-X

[22] Goso, C.A. and Muzio, R. (2006) Geología de la costa uruguaya y sus recursos minerales asociados. In: Menafra, R., Rodríguez-Gallego, L., Scarabino, F. and Conde, D., Eds., Bases para la conservación y el manejo de la costa uruguaya, Vida Silvestre Uruguay, Montevideo, 9-19.

[23] Panario, D. and Gutiérrez, O. (2006) Dinámica y fuentes de sedimentos de las playas uruguayas. In: In: Menafra, R., Rodríguez-Gallego, L., Scarabino, F. and Conde, D., Eds., Bases para la conservación y el manejo de la costa uruguaya, Vida Silvestre Uruguay, Montevideo, 21-34.

[24] Ríos, M., Bartesaghi, L., Piñeyro, V., Garay, A., Mai, P., Delfino, L., Masciadri, S., Alonso Paz, E., Bassagoda, M. and Soutullo, A. (2010) Caracterización y distribución espacial del bosque y matorral psamófilo. Avaiable from Grupo Guayubira Informe No 23. Proyecto Fortalecimiento del Proceso de Implementación del Sistema Nacional de Áreas Protegidas del Uruguay, SNAP-Ecoplata

[25] De Álava, D. and Canario, D. (1996) La costa atlántica del Uruguay. Ecosistemas perdidos y el nacimiento de un monte de pinos y acacias. Almanaque Banco de Seguros del Estado, 44-51. http://www.bse.com.uy/inicio/almanaques/almanaque-1996

[26] Capocasale, R.M. (1990) Las especies de la subfamilia Hipassinae de América del Sur (Araneae, Lycosidae). The Journal of Arachnology, 18, 131-141.

[27] Costa, F.G. (1995) Ecología y actividad diaria de las arañas de la arena Allocosa spp. (Araneae, Lycosidae) en Marindia, localidad costera del sur del Uruguay. Revista Brasileira de Biologia, 55, 457-466. 
[28] Aisenberg, A. and Peretti, A.V. (2011) Male Burrow Digging in a Sex-Role Reversed Spider Inhabiting Water-Margin Environments. Bulletin of the British Arachnological Society, 15, 201-204. http://dx.doi.org/10.13156/arac.2011.15.6.201

[29] Aisenberg, A., González, M., Laborda, A., Postiglioni, R. and Simó, M. (2011) Spatial Distribution, Burrow Depth and Temperature: Implications for the Sexual Strategies in Two Allocosa Wolf Spiders. Studies of Neotropical Fauna Environment, 46, 147-152. http://dx.doi.org/10.1080/01650521.2011.563985

[30] Aisenberg, A., Viera, C. and Costa, F.G. (2007) Daring Females, Devoted Males and Reversed Sexual Size Dimorphism in the Sand-Dwelling Spider Allocosa brasiliensis (Araneae, Lycosidae). Behavioral Ecology and Sociobiology, 62, 29-35. http://dx.doi.org/10.1007/s00265-007-0435-x

[31] Aisenberg, A. and Costa, F.G. (2008) Reproductive Isolation and Sex Role Reversal in Two Sympatric Sand-Dwelling Wolf Spiders of the Genus Allocosa. Canadian Journal of Zoology, 86, 648-658. http://dx.doi.org/10.1139/Z08-040

[32] Aisenberg, A., González, M. and Costa, F.G. (2011) Male Sexual Cannibalism in a Sand-Dwelling Wolf Spider with Sex Role Reversal. The Biological Journal of the Linnean Society, 103, 68-75. http://dx.doi.org/10.1111/j.1095-8312.2011.01631.x

[33] Ghione, S., Simó, M., Aisenberg, A. and Costa, F.G. (2013) Allocosa brasiliensis (Araneae, Lycosidae) as a Bioindicator of Coastal Sand Dunes in Uruguay. Arachnology, 16, 94-98. http://dx.doi.org/10.13156/100.016.0304

[34] Shook, R.S. (1978) Ecology of the Wolf Spider, Lycosa carolinensis Walckenaer (Araneae, Lycosidae) in a Desert Community. The Journal of Arachnology, 6, 53-64.

[35] Nørgaard, T., Henschel, J.R. and Wehner, R. (2007) Use of Local Cues in the Night-Time Navigation of the Wandering Desert Spider Leucorchestris arenicola (Araneae, Sparassidae). Journal of Comparative Physiology A, 193, 217222. http://dx.doi.org/10.1007/s00359-006-0178-6

[36] Buddle, C.M. and Rypstra, A.L. (2003) Factors Initiating Emigration of Two Wolf Spider Species (Araneae: Lycosidae) in an Agroecosystem. Environmental Entomology, 32, 88-95. http://dx.doi.org/10.1603/0046-225X-32.1.88

[37] Kiss, B. and Samu, F. (2000) Evaluation of Population Densities of the Common Wolf Spider Pardosa agrestis (Araneae: Lycosidae) in Hungarian Alfalfa Fields Using Mark Recapture. European Journal of Entomology, 97, 191-195. http://dx.doi.org/10.14411/eje.2000.036

[38] Matteucci, S.D. and Colma, A. (1982) Metodología para el estudio de la vegetación. Mon. O.E.A. Ser. Biol. No. 22.

[39] Fernández-Montraveta, C. and Cuadrado, M. (2008) Microhabitat Selection in the Potentially Endangered Wolf Spider Donacosa merlini (Araneae, Lycosidae): Implications for Spider Conservation. Canadian Journal of Zoology, 86, 1280-1288. http://dx.doi.org/10.1139/Z08-113

[40] Finch, O.D. (2005) Evaluation of Mature Conifer Plantations as a Secondary Habitat for Epigeic Forest Arthropods (Coleoptera; Carabidae; Araneae). Forest Ecology and Management, 204, 21-34. http://dx.doi.org/10.1016/j.foreco.2004.07.071

[41] Aisenberg, A., Costa, F.G., González, M., Postiglioni, R. and Pérez-Miles, F. (2010) Sexual Dimorphism in Chelicerae, Forelegs and Palpal Traits in Two Burrowing Wolf Spiders (Araneae: Lycosidae) with Sex-Role Reversal. Journal of Natural History, 44, 1189-1202. http://dx.doi.org/10.1080/00222931003632716

[42] Rodrigues, E.N., De, S., Mendonça, M., Rosado, J.L.O. and Loeck, A.E. (2010) Soil Spiders in Differing Environments: Eucalyptus Plantations and Grasslands in the Pampa Biome, Southern Brazil. Revista Colombiana de Entomología, 36, 277-284.

[43] Jongman, R.H., Ter Braak, C.J.F. and Van Tongeren, O.F.R. (1995) Data Analysis in Community and Landscape Ecology. Cambridge University Press, Cambridge. http://dx.doi.org/10.1017/cbo9780511525575

[44] Uehara-Prado, M., de Oliveira Fernandes, J., de Moura Bello, A., Machado, G., Santos, A.J., Zagury Vaz-de-Mello, F. and Lucci Freitas, A.V. (2009) Selecting Terrestrial Arthropods as Indicators of Small-Scale Disturbance: A First Approach in the Brazilian Atlantic Forest. Biological Conservation, 142, 1220-1228. http://dx.doi.org/10.1016/j.biocon.2009.01.008

[45] Murray, T.J., Dickinson, K.J.M. and Barratt, B.I.P. (2006) Associations between Weevils (Coleoptera: Curculionoidea) and Plants, and Conservation Values in Two Tussock Grasslands, Otago, New Zealand. Biodiversity and Conservation, 15, 123-137 http://dx.doi.org/10.1007/s10531-004-4246-3

[46] Clarke, K.R. and Warwick, R.M. (1994) Similarity-Based Testing for Community Pattern: The Two-Way Layout with No Replication. Marine Biology, 18, 167-176. http://dx.doi.org/10.1007/BF00699231

[47] QGIS Development Team (2013) QGIS Geographic Information System. Open Source Geospatial Foundation Project. http://qgis.osgeo.org

[48] Hammer, Ø., Harper, D.A.T. and Ryan, P.D. (2001) PAST: Paleontological Statistics Software Package for Education and Data Analysis. Palaeontologia Electronica, 4, 1-9. http://palaeo-electronica.org/2001 1/past/issue1 01.htm 
[49] Ramírez, M.G. and Haakonsen, K.E. (1999) Gene Flow among Habitat Patches on a Fragmented Landscape in the Spider Argiope trifasciata (Araneae: Araneidae). Heredity, 83, 580-585. http://dx.doi.org/10.1038/sj.hdy.6885630

[50] Dieckmann, U., O’Hara, B. and Weiser, W.W. (1999) The Evolutionary Ecology of Dispersal. Trends in Ecology and Evolution, 14, 88-94. http://dx.doi.org/10.1016/S0169-5347(98)01571-7

[51] Bell, J.R., Haughton, A.J., Rod Cullen, W. and Philip Wheater, C. (1998) The Structure of Spider Communities in Limestone Quarry Environments. Proceedings of the 17th European Colloquium of Arachnology, Edinburgh, 14-18 July 1997, 261-266.

[52] Almquist, S. (1973) Habitat Selection by Spiders on Coastal Sand Dunes in Scania, Sweden. Entomological Scandinavian, 4, 134-154. http://dx.doi.org/10.1163/187631273X00174

[53] Marshall, S.D. (1995) Natural history, Activity Patterns, and Relocation Rates of a Burrowing Wolf Spider: Geolycosa xera archboldi (Araneae, Lycosidae). The Journal of Arachnology, 23, 65-70.

[54] Alonso-Paz, E. and Bassagoda, M.J. (2006) Flora y vegetación de la costa platense y atlántica uruguaya. In: Menafra, R., Rodríguez-Gallego, L., Scarabino, F. and Conde, D., Eds., Bases para la conservación y el manejo de la costa uruguaya, Vida Silvestre Uruguay, Montevideo, 71-88.

[55] Harrison, S. and Bruna, E. (1999) Habitat Fragmentation and Large-Scale Conservation: What Do We Know for Sure? Ecography, 22, 225-232. http://dx.doi.org/10.1111/j.1600-0587.1999.tb00496.x

[56] Bolger, D.T., Beard, K.H., Suarez, A.V. and Case, T.J. (2008) Increased Abundance of Native and Nonnative Spiders with Habitat Fragmentation. Diversity Distributions, 14, 655-665. http://dx.doi.org/10.1111/j.1472-4642.2008.00470.x

[57] Major, R.E., Gowing, G., Christie, F.J., Gray, M. and Colgan, D. (2006) Variation in Wolf Spider (Araneae: Lycosidae) Distribution and Abundance in Response to the Size and Shape of Woodland Fragments. Biology Conservation, 132, 98-108. http://dx.doi.org/10.1016/j.biocon.2006.03.017 